\title{
Global Labour: A Not-so-grand Finale and Perhaps a New Beginning
}

\section{Marcel van der Linden, University of Amsterdam, The Netherlands}

Traditional labour movements are in trouble almost everywhere. ${ }^{1}$ They have been severely enfeebled by the political and economic changes of the last forty years. Their core consists of three forms of social movement organisations: cooperatives, trade unions and workers' parties. All three organisational types are in decline, though this is an uneven development with vast differences between countries and regions. We are living through a transitional stage in which old organisational structures no longer seem to work well, while new structures are still in their early stages.

\section{Consumer Cooperatives}

Since the 1940s and 1950s, consumer cooperatives, like all businesses under capitalism, were increasingly forced to concentrate capital, due to improved transportation facilities and new retail forms. This trend manifested itself partly in the declining number of cooperatives, and also in the increasing membership strength of each cooperative unit (Pestoff, 1991: 234; Gurney, 1996: 242). Often the average age of members rose, as elderly members remained loyal to their cooperatives, and younger ones failed to materialise. Generally, consumer cooperatives were doomed by inhibitions arising from their pioneering role. Established in an era when small shop-owners controlled retailing, they were initially at an advantage. Their larger operations were more economically rational and offered advantages of scale. In response, shopkeepers joined forces and developed chain stores, central purchasing organisations, self-service stores, supermarkets, shopping centres and the like. These new types of businesses featured brand names, systems of accumulated redeemable credits, low prices and enticing advertisements. As a result, the competitive advantage of the consumer cooperatives deteriorated rapidly. The surplus base (surplus divided by sales) decreased, along with the dividends for members and the opportunities for innovation and investment. Many consumer cooperatives encountered financial difficulties, and faced a serious dilemma in their effort to avoid bankruptcy. Their limited choices included merging with a regular capitalist business, becoming a limited liability company, or borrowing substantial amounts from banks. In each case, they ceased to be autonomous cooperatives. Another approach involved countering the rising competition through modernisation and operational expansion, thereby increasing the social distance between members and administrators, as well as further reducing involvement among the members and thereby undermining the organisation's cooperative nature.

\footnotetext{
1 This article is partly based on a research note written for the International Panel on Social Progress (www.ipsp.org). I have profited from suggestions made by Naila Kabeer, Ronaldo Munck and Peter Wagner. Some paragraphs have been borrowed from Van der Linden (2010, 2015).
} 


\section{Trade Unions}

Independent mass trade unions had their origin in the nineteenth century, and exist today in large parts of the world - although there are also major regions where they have almost no influence. The most striking example of a fast-growing capitalist economy without independent trade unions is the People's Republic of China (PRC). It hosts the world's largest workers' organisation, the All-China Federation of Trade Unions (ACFTU), which has more than 280 million members. This is not an independent union, however, but rather a transmission belt for the Chinese Communist Party. Most of the numerous labour conflicts in the People's Republic do not take place with the support of the ACFTU (Bai, 2012).

In countries with independent workers' organisations, union density (union members as a percentage of the total labour force) has generally been declining. Table 1 shows the trends in a number of countries with more than 50 million inhabitants in 2010, for the period 1960-2013.

Table 1: Union densities in selected countries, 1960-2013

\begin{tabular}{|c|c|c|c|c|c|c|c|}
\hline Country & 1960 & 1970 & 1980 & 1990 & 2000 & 2010 & 2013 \\
\hline Brazil & n.a. & n.a. & $\begin{array}{l}20.8 \\
(1976)\end{array}$ & 26.7 & 28.3 & 26.5 & 16.6 \\
\hline China PR & n.a. & n.a. & $(58.6)$ & $(76.6)$ & $\begin{array}{l}(62.3) \\
(1997)\end{array}$ & (34.7) & $(42.6)$ \\
\hline France & 19.6 & 21.7 & 18.3 & 10.0 & 8.0 & 7.9 & 7.7 \\
\hline Germany & $34.7^{*}$ & $32.0^{*}$ & $34.9^{*}$ & 31.2 & 24.6 & 18.6 & $17.7 t$ \\
\hline India & n.a. & n.a. & n.a. & n.a. & $\begin{array}{l}13.8 \\
(2004)\end{array}$ & $\begin{array}{l}10.2 \\
(2009)\end{array}$ & $\begin{array}{l}9.8 \\
(2012)\end{array}$ \\
\hline Italy & 24.7 & 37.0 & 49.6 & 38.8 & 34.8 & 36.0 & $36.9 \dagger$ \\
\hline Japan & 32.9 & 35.1 & 31.1 & 25.4 & 21.5 & 18.4 & 17.8 \\
\hline Malaysia & n.a. & n.a. & n.a. & 16.5 & 10.7 & 9.1 & 9.4 \\
\hline Mexico & & & & & $15.6 \dagger$ & $14.4 \dagger$ & $13.6 \dagger$ \\
\hline Philippines & n.a. & n.a. & 27.0 & 29.7 & 27.1 & 8.7 & 8.5 \\
\hline Russian Federation & & $\begin{array}{l}100.0 \\
(1968)\end{array}$ & $\begin{array}{l}100.0 \\
(1979)\end{array}$ & 72.0 & $\begin{array}{l}55.6 \\
(1999) \\
\end{array}$ & 30.7 & 27.8 \\
\hline South Africa & n.a. & n.a. & n.a. & n.a. & $39.1 \ddagger$ & $29.7 \ddagger$ & n.a. \\
\hline South Korea & n.a. & n.a. & n.a. & n.a. & $11.4 \dagger$ & $9.7 \dagger$ & n.a. \\
\hline Turkey & 10.8 & 25.9 & 42.1 & 24.0 & 12.4 & 7.0 & 6.5 \\
\hline $\mathrm{UK}$ & 40.4 & 44.8 & 51.7 & 39.7 & 30.1 & 27.1 & $25.4 \dagger$ \\
\hline USA & n.a. & $23.5 \triangleright$ & $19.5 \diamond$ & $15.5 \diamond$ & $\begin{array}{l}12.9 \dagger \\
12.8 \diamond\end{array}$ & $11.4 \dagger$ & $10.8 \dagger$ \\
\hline
\end{tabular}

* Germany $=$ West Germany for 1960-1990. $\quad$ †OECD figures (stats.oecd.org). FILOSTAT (mmw.ilo.org/ ilostat). VJelle Visser, (2006: 38-49).

Countries included were those that had a population greater than 50 million in 2010.

The following countries have not been included due to lack of data: Argentina, Bangladesh, Colombia, Democratic Republic of Congo, Egypt, Ethiopia, Indonesia, Iran, Myanmar, Nigeria, Pakistan, Tanzania and Vietnam.

All percentages indicate net union membership as a proportion of wage and salary earners in employment, unless these figures are not available.

Additional source: ICTWSS Database, Amsterdams Institunt voor Arbeidsstudies (www.wva-aias.net/207), version 4, April 2013. 
On a global scale union density is almost insignificant. Independent trade unions organise only a small percentage of their target group worldwide, and the majority of them live in the relatively wealthy North Atlantic region. By far the most important global umbrella organisation is the International Trade Union Confederation (ITUC), founded in 2006 as a merger of two older organisations, the secular reform-oriented International Confederation of Free Trade Unions (ICFTU) and the Christian World Confederation of Labour (WCL). In 2014 the ITUC estimated that about 200 million workers worldwide belonged to trade unions (excluding those of China), and that 176 million of these were organised in the ITUC. ${ }^{2}$ The ITUC also estimates that the total number of workers is roughly 2.9 billion (of whom 1.2 billion are in the informal economy). Therefore, global union density currently amounts to no more than 7 per cent! (ITUC, 2014: 8).

A number of factors have contributed to the weakness of the unions. Firstly, the composition of the working class is changing. Unions find it difficult to organise employees in the service or financial sector. The rapidly growing informal economy is a further complicating factor, since workers are provided with short contracts, tend to change jobs frequently, and work under often very precarious conditions. Another important factor is what labour economist Richard Freeman (2010) has called the "labour supply shock" which has manifested itself since the early 1990s. Through the entry of Chinese, Indian, Russian and other workers into the global economy, there has been an effective doubling of the number of workers producing for international markets over the past two decades.

A decline in the global capital/labor ratio shifts the balance of power in markets away from wages paid to workers and toward capital, as more workers compete for working with that capital. ... Even considering the high savings rate in the new entrants - the World Bank estimates that China has a savings rate of 40\% of GDP - it will take 30 or so years for the world to re-attain the capital/labor ratio among the countries that had previously made up the global economy. Having twice as many workers and nearly the same amount of capital places great pressure on labor markets throughout the world. This pressure will affect workers in the developing countries who had traditionally participated in the global economy, as well as workers in advanced countries (Freeman, 2010: n.p.)

Secondly, significant economic shifts have taken place. The growth of foreign direct investment in the core countries and the semi-periphery of the world economy has been impressive, and transnational corporations and multi-state trading blocs - such as the European Union, the North American Free Trade Agreement and Mercosur - have multiplied, thus increasing outsourcing and relocation of production. Brazil, India and especially China are important new players who change the rules of the game. This is accompanied by new supranational institutions, such as the World Trade Organization, established in 1995.

And thirdly, in many countries there has been a strong neo-liberal offensive against the old-

2 This calculation is probably misleading. A significant, but unknown, part of the union membership consists of pensioners. It is therefore likely that the number of employed or employable members is lower.

Global Labour Journal, 2016, 7(2), Page 203 
style unions and their modus operandi: the dominant practice of collective bargaining has increasingly become decentralised, and individualised labour contracts have become much more widespread than before. There have also been very direct attacks on unions, notably in the countries that experienced neo-liberal regime shifts like the US und UK. Weakened trade unions have to face more and more competition from alternative structures that are better adapted to the new style of labour relations. In Brazil, South Africa, the Philippines and South Korea militant workers' movements (social movement unions) have emerged (Scipes, 2014). New forms of rank-and-file trade unionism outside the established channels have been appearing since the 1970s, with international connections at the shop-floor level "bypassing altogether the secretariats, which they see as too often beholden to the bureaucracies of their various national affiliates" (Herod, 1997: 184). A well-known example is the Transnationals Information Exchange (TIE), a centre in which a substantial number of research and activist labour groups exchange information on trans-national corporations (TNCs). The ineffectiveness of old-style unions is underlined by the growing tendency on the part of international trade union secretariats (now called Global Unions) to engage in the direct recruitment of members in the periphery. We may think, for example, of the activities of the Union Network International (the global union for the service sector), which started recruiting IT specialists in India directly, thus bypassing local unions.

\section{Workers' Parties}

Labour, social democratic and communist parties are generally considered to be political representatives of the working class. The oldest parties, the social democratic and labour parties, are not doing very well electorally. Table 2 indicates that of the fifteen parties listed, twelve reached their apex between 1940 and 1989; Switzerland was earlier (1930s), while Portugal and Brazil were later (early twenty-first century). More important, though, is that this family of parties is struggling with a fundamental identity problem. Social democratic and labour policies have since the 1930s and 1940s been based on two pillars: social Keynesianism and a specific "red" party subculture with its own sports associations, women's clubs, organisations for nature lovers, consumer cooperatives, newspapers, theatre groups and the like.

The sociocultural and economic reversal since the 1960s and 1970s toppled both "pillars" of the social Keynesian stage, as the parties' subcultural networks - youth, women's and sports organisations, theatre clubs, etc. - fell to pieces and social Keynesianism became less feasible due to economic crises and globalisation. A great many challenges had to be met more or less simultaneously. Traditional centralism had to be reconciled with grassroots movements, and feminism with the conventional androcentric culture. Moreover, the environmental movement needed to be taken seriously without abandoning the pursuit of economic growth (the condition for social redistribution in a capitalist context). Generalised confusion resulted in a tremendous increase of floating voters, ageing and decreasing membership numbers, and the virtual disappearance of active proletarian members, thus weakening the social ties with trade unions.

Communist parties are the second major political form. Most of them were born or grew significantly in three waves: from mid-1918 to 1923 in the aftermath of the October Revolution; in the 1930s as a response to the economic depression; and during and immediately after the Second World War. Some parties still have a rather solid, although often small, base, such as the ones in Portugal, Spain and Greece. These parties all developed under right-wing dictatorships and are 
characterised by their intransigence. Similarly, the influential South African Communist Party (SACP) seems still to have a significant influence on the politics of the African National Congress (ANC).

\begin{tabular}{|c|c|c|c|c|c|c|c|c|c|c|}
\hline & $\begin{array}{l}1920- \\
1929\end{array}$ & $\begin{array}{l}1930- \\
1939\end{array}$ & $\begin{array}{l}1940- \\
1949\end{array}$ & $\begin{array}{l}1950- \\
1959\end{array}$ & $\begin{array}{l}1960- \\
1969\end{array}$ & $\begin{array}{l}1970- \\
1979\end{array}$ & $\begin{array}{l}1980- \\
1989\end{array}$ & $\begin{array}{l}1990- \\
1999\end{array}$ & $\begin{array}{l}2000- \\
2009\end{array}$ & $\begin{array}{l}2010- \\
2015\end{array}$ \\
\hline Australia & 45.2 & 32.4 & 46.5 & 46.3 & 45.1 & 45.4 & 47.0 & 40.8 & 39.2 & 35.7 \\
\hline Austria & 39.3 & 41.1 & 41.7 & 43.3 & 50.0 & 45.4 & $47.6^{*}$ & 37.3 & 33.7 & $26.8^{*}$ \\
\hline Belgium & 36.7 & 33.1 & 30.7 & 35.9 & 31.0 & 26.6 & 28.0 & 23.2 & 24.0 & 21.7 \\
\hline Brazil & - & - & - & - & - & - & - & 12.1 & 16.8 & 15.4 \\
\hline Denmark & 34.5 & 43.9 & 39.1 & 40.2 & 39.1 & 33.6 & 30.9 & 36.0 & 26.8 & 25.6 \\
\hline France & 19.1 & 20.2 & 20.9 & 15.1 & 15.9 & 21.0 & 35.3 & 34.6 & 38.8 & $29.4^{*}$ \\
\hline Germany & 29.3 & 21.2 & 29.2 & $30.3 \#$ & $39.4 \#$ & 44.2\# & $39.4 \#$ & 36.9 & 31.9 & $25.7^{*}$ \\
\hline Italy & $24.7 *$ & - & {$[20.7]$} & 13.5 & 13.8 & 9.7 & 12.9 & $7.9^{* *}$ & - & - \\
\hline Netherlands & 22.0 & 21.7 & 27.0 & 30.7 & 25.8 & 28.6 & 31.0 & 26.5 & 21.2 & 24.8 \\
\hline Norway & 25.5 & 38.0 & 43.4 & 47.5 & 45.5 & 38.8 & 27.4 & 36.0 & 30.8 & $30.8^{*}$ \\
\hline Portugal & - & - & - & - & - & 35.2 & 27.6 & 39.0 & 39.8 & 30.2 \\
\hline Spain & - & 23.1 & - & - & - & 30.4 & 44.1 & 38.2 & 40.2 & 25.4 \\
\hline Sweden & 36.0 & 43.8 & 48.8 & 45.6 & 48.4 & 43.7 & 44.5 & 39.8 & 37.5 & 30.9 \\
\hline Switzerland & 25.5 & 27.5 & 27.4 & 26.5 & 25.1 & 24.1 & 20.7 & 20.9 & 21.4 & $18.7^{*}$ \\
\hline $\begin{array}{l}\text { United } \\
\text { Kingdom }\end{array}$ & 37.7 & 34.4 & $49.7 *$ & 46.3 & 46.1 & 39.1 & 29.2 & 38.7 & 38.0 & 29.7 \\
\hline
\end{tabular}

* Only one election **Party disbanded in November $1994 \quad$ \# Numbers between 1950 and 1990 refer to West Germany

But for most communist parties the high point was in the 1940s; now, many of them are having a hard time. In quite a few countries the parties were dissolved after electoral decline, splits or financial bankruptcy. This has been the case in Britain (dissolved 1991), Italy (disbanded 1991), Finland (bankrupt 1992) and Brazil (internal coup and split 1992). Other parties have gone through mergers, for example in Mexico (founding of the Unified Socialist Party in 1981), Denmark (formation of the Red-Green Alliance in 1989) and the Netherlands (founding of the Green Left Party in 1989). Even the Communist Party of India Marxist (CPI-M) in West Bengal, which received a majority of the votes in a whole series of elections from the 1970s until 2011, has now been reduced to a minor player (only two out of forty-two seats) because of its violent neo-liberal policies.

\section{Signs of Renewal}

All in all, the foregoing seems to suggest three things. On a world scale, consumer cooperatives have either not been doing well, or they have morphed into retail industries without members democratically controlling the business. Trade unions are not only a weak force, but their power is also decreasing; and in many countries trade unions have lost their natural allies, the workers' parties, either because these parties have disappeared or because they have adopted a variant of neo- 
liberalism. As a consequence, both local and international NGOs have partly shouldered activities that would previously have been the responsibility of the international trade union movement, such as the struggle to regulate and abolish child labour. The downturn of labour movements seems to be almost all-embracing.

In these circumstances, what are the prospects for workers' movements? In the long run, things may not be as gloomy as they seem today. A number of factors may change, thus enabling a more optimistic future.

First, class conflicts will not diminish and workers all over the world will continue to feel the ever-present need for effective organisations and forms of struggle. Indirect support for this assertion comes from the religious and nationalist movements which partly fill the currently existing social void by deflecting class conflicts. They offer their supporters elementary forms of social security and trust networks, as well as self-esteem and clear life goals. Many poor people are drawn into such movements, in all their variants - from the Pentecostalist movements of Latin America and Sub-Saharan Africa, to Salafism in North Africa, the Middle East and Central Asia. Precarious youth in capitalist industrial cities likewise appear sometimes to be attracted to groups offering a new religious certainty. Historian Sabyasachi Bhattacharya (2016: 2) calls this trend the "vernacularization of labour politics"; it creates "solidarity of people with a common cause which may be social or cultural or sometimes regressively religious; the solidarity thus obtained can be and is used to pursue an agenda that runs parallel with or replaces the trade unions' agenda". A clear right-wing example is the Hindu-fascist Shiv Sena movement, which gained influence after the defeat of the big textile workers strike in Bombay in 1980-1981. The social plagues of casualisation, immiseration, increasing petty crime and trafficking made the Shiv Sainiks popular very quickly. They offered the poor not only honour, status and self-respect, but also cooperated with yellow "trade unions", which offered some protection (Heuzé-Briguant, 1999).

Second, the global labour force is larger than ever before. A recent ILO study revealed that in the period 1980-2005 the labour force in the Middle East and North Africa region had grown by 149 per cent. In Sub-Saharan Africa, Latin America and the Caribbean it had roughly doubled, in South Asia it had increased by 73 per cent, and in East and South East Asia by 60 per cent (Kapsos, 2007). Simultaneously, enormous shifts are taking place within separate regions. A historic migration from the countryside to swelling megacities is under way. In 2000, the National Bureau of Statistics of the People's Republic of China estimated that there were 113 million rural migrant workers in the country. Ten years later that number had more than doubled to 240 million, including 150 million working outside their home areas. Of those 150 million about 72 per cent were employed in manufacturing, construction, food and beverage, wholesale and retail industries, and hospitality (CLB, 2012: 4). In India, internal labour migration has exploded since the 1990s, the temporary and seasonal migration rate being highest in poor regions like Nagaland and Madya Pradesh (Bhagat and Mohanty, 2009).

Third, such shifts are often accompanied by an intensification of social struggles. In Indonesia, the Konfederasi Serikat Pekerja Indonesia (Indonesian Trade Union Confederation) organised a national strike on 3 October 2012, and a second one - demanding a 50 per cent increase of the minimum wage - on 31 October and 1 November 2013. These were not truly general strikes, but they nevertheless were joined by hundreds of thousands of workers, especially in the Jakarta region. In India, on 20 and 21 February 2013, over one hundred million workers across the country struck for a list of demands including a living wage indexed to inflation, universal food security and equal 
pay for equal work. In China, the labour shortages that began to emerge from 2004, led to a rapid growth of workers' protests, which have "not only increased in number but have shifted focus from a reactive response to labour rights violations towards more proactive demands for higher wages and improved working conditions" (CLB, 2012: 5) The Chinese Academy of Social Sciences reported that there were more than 60000 so-called "mass incidents" (popular protests by waged workers and others, such as peasants and the quasi-religious group Falun Gong) in 2006, and over 80000 in 2007. Since then, official figures on "mass incidents" have no longer been published but experts believe that in recent years the number has further increased (CLB, 2012: 9). Since the beginning of the economic crisis more than thirty national strikes occurred in Greece, while Spain and Portugal saw several general strikes. The dramatic overthrow of the Mubarak dictatorship in Egypt in 2011 could not have happened without the labour movement's strong support. And in South Africa massive and often violent strikes follow one another rapidly. There is, therefore, a lot of militancy, but this is not matched by the strength of labour organisations.

Fourth, during the last decade social protests have grown in all regions of the world:

... despite the absence of exactitude in measurement, data from the past several decades do point to a fairly clear pattern of increasing frequency. Major protests multiplied in the second half of the 1980s and early 1990s, coinciding with what is commonly called the third wave of democracy, but then decreased significantly throughout the 1990s and the first half of the 2000s. Protests began to accelerate again in the second half of the 2000s and have reached a peak in the past five years [i.e. 2011-2015] (Carrothers and Youngs, 2015: 5; see also Ortiz et al., 2013; Economist Intelligence Unit, 2013).

The large majority of protest events address their grievances to their own national governments, and demand that these governments develop economic, social and environmental policies that are in the interest of the population at large, and not of only the wealthy and powerful. The demands put forward by protesters are generally sundry, and the forms protests take are heterogeneous. Protests oppose many things: the elimination of subsidies on food and fuel; wage cuts; VAT increases on basic goods and services; the emaciation of social security; the reform of pension and health care systems; the flexibilisation of labour; but also pollution, war, rape and corporate influence. The lack of "real democracy" is a regular issue. Protests are more frequent in high-income countries, and more often turn violent in low-income countries. Most protests do not achieve an alleviation of their grievances, at least in the short run (Ortiz et al., 2013: 34).

Fifth, there are also explicit signs of a renewal. Organising drives for previously unorganised workers in hospitals and the care sector in general have been increasing over the past few years. The rise of the International Domestic Workers Network since 2009, and their campaign resulting in ILO Convention 189 on Decent Work for Domestic Workers (ILO, 2011) has been an inspiration for many. The current strike wave of incarcerated workers in the United States reveals that new segments of the working class are beginning to be mobilised. In many countries trade unions are trying to open up to "informal" and "illegal" workers. Quite spectacular is India's New Trade Union Initiative (NTUI), founded in 2006, which recognises the importance of both paid and unpaid women's work; it attempts to organise not only the "formal" sector, but also contract workers, casual workers, household workers, the self-employed, and the urban and rural poor; it also tries to restructure collective bargaining frameworks accordingly.

Global Labour Journal, 2016, 7(2), Page 207 


\section{Prospects}

There is an important obstacle to the renewal of labour movements, which makes successes difficult to effect: during the last four or five decades national states have lost much of their sovereignty, but this loss of power has not been compensated by supranational (or world) authorities. We live in a transitional period in which many challenges can no longer be dealt with by national authorities, and not yet (if ever) by supranational authorities.

In the contemporary global world there is no equivalent of the nation state at the world level that could implement fiscal and welfare policies, anti-trust controls, labour and environmental laws aimed at regulating markets and at correcting market failures. Nor is there a world independent judiciary which can control and sanction illegal behavior. Nor is there a democratic polity at the world level ... (Martinelli, 2005: 247).

This helps to explain the "negative" attitude of many social movements that say "no" to certain developments and have no positive alternative, because this would require a world authority. Nevertheless, transnational action focused on states is possible even under these adverse circumstances - either by pressing national governments to coordinate policies across borders, or by exemplary local activities that can inspire movements in other parts of the world.

A new labour movement will have to find an internationalist approach that is based on crossborder solidarity, even under these adverse circumstances. It can partly find its foundations in the old labour movements, but these will have to be change considerably. The contours of the new international trade unionism still remain vague, but several minimum conditions are already clearly apparent. These include the following:

- The target group has to be demarcated anew. The first-phase demarcation of the working classes in the nineteenth century was extremely narrow and Eurocentric, and needs to be revised and expanded. A considerable number of trade unions in the periphery and semiperiphery have now abandoned the old demarcation, and recruit all kinds of subaltern workers.

- There can be no doubt that the newly-defined target group will no longer be dominated by white male workers in the North Atlantic region, but by women and people of colour, many in forms of self-employment, precarious jobs or debt bondage. Trade unions will need to effect a drastic change in their operational systems, in order to assist these "new" workers to further their interests effectively. This also implies ending the centrality of collective bargaining strategies.

- The dual structure of the international trade union movement - collaboration of national confederations in the ITUC plus Global Union Federations - is a problematic relic of the past and likely to be discarded. Probably the best option would be a new unitary structure facilitating the inclusion of the "new" target groups in the Global Unions.

- The somewhat autocratic approach prevailing in the present-day international trade union movement has to be replaced by a democratic approach, and greater participation of the rank-and-file workers. The possibilities offered by the Internet could make a positive 
contribution to a renewed structure of this kind.

- While lobbying governments and transnational organisations has to date been the principal activity of the international trade union movement (with the notable exception of the antiapartheid campaign of the 1980s), and efforts are made to cultivate the good will of states, effective action requires much greater effort in active measures, such as boycotts, strikes and so on, which in turn demands a substantial strengthening of internal structures.

The question is whether the existing international trade union movement can meet these challenges. It is likely that the formation of new movements will be a difficult process, interspersed with failed experiments and moments of deep crisis. Organisational structures and patterns of behaviour that have existed for over a century are not easily changed. Moreover, it is highly unlikely that new structures and patterns will be shaped through reforms from above, through the central leaderships. If there is one thing that history has taught us, it is that trade union structures almost never develop smoothly by means of piecemeal engineering. They are generally the outcome of conflicts and risky experiments. Pressure from below (through competitive networks and alternative action models) will be a very important factor in deciding that outcome.

\section{REFERENCES}

Bai, Ruixue (2012) The Role of the All China Federation of Trade Unions: Implications for Workers Today. In China's Rise: Strength and Fragility, edited by Au Loong Yu, Bai Ruixue, Bruno Jetin and Pierre Rousset. London: Merlin.

Bhagat, R.B. and S. Mohanty (2009) Emerging Pattern of Urbanization and the Contribution of Migration in Urban Growth in India. Asian Population Studies, 5/1: 5-20.

Bhattacharya, Sabyasachi (2016) Introduction. In The Vernacularization of Labour Politics, edited by Sabyasachi Bhattacharya and Rana P. Behal. New Delhi: Tulika.

Carothers, Thomas and Richard Youngs (2015) The Complexities of Global Protests. Washington, DC: Carnegie Endowment for International Peace.

China Labour Bulletin (CLB) (2012) A Decade of Change. The Workers' Movement in China 2000-2010. CLB Research Report, March. Hong Kong: CLB.

China Labour Bulletin (CLB) (2014) Searching for the Union. The Workers' Movement in China 2011-13. CLB Research Report, February. Hong Kong: CLB.

Economist Intelligence Unit (2013) Rebels without a Cause: What the Upsurge in Protest Movements Means for Global Politics. Available online at http://www.eiu.com/ProtestUpsurge.

Freeman, Richard (2010) What Really Ails Europe (and America): The Doubling of the Global Labor Force. The Globalist, 5 March 2010.

Gurney, Peter (1996) Co-operative Culture and the Politics of Consumption in England, 1870-1930. Manchester and New York: Manchester University Press.

Heuzé-Briguant, Gérard (1999) Populism and the Workers Movement: Shiv Sena and Labour in Mumbai. South Asia: Journal of South Asian Studies, 22(2): 119-148. 
Herod, Andrew (1997) Labor as an Agent of Globalization and as a Global Agent. In Spaces of Globalization: Reasserting the Power of the Local, edited by Kevin R. Cox. New York: The Guilford Press.

International Labour Organisation (ILO) (2011) Convention 189 on Decent Work for Domestic Workers. Geneva: ILO.

International Trade Union Confederation (ITUC) (2014) Building Workers' Power. Congress Statement. Berlin: ITUC.

Kapsos, Steven (2007) World and Regional Trends in Labour Force Participation: Methodologies and Key Results. Geneva: ILO.

Martinelli, Alberto (2005) From World System to World Society? Journal of World-Systems Research, 11(2): 241-260.

Ortiz, Isabel, Sara Burke, Mohamed Berrada and Hernán Cortés (2013) World Protests 2006-2013. New York: Initiative for Dialogue Policy and Friedrich-Ebert-Stiftung.

Pestoff, Victor A. (1991) Between Markets and Politics. Co-operatives in Sweden. Frankfurt/Main: Campus, and Boulder, Col.: Westview.

Scipes, Kim (2014) Building Global Labor Solidarity Today: Learning from the KMU of the Philippines. Class, Race and Corporate Power, 3(1): Article 4. Available online at http://digitalcommons.fiu.edu/classracecorporatepower/vol3/iss1/4.

Van der Linden, Marcel (2010) Workers of the World: Essays toward a Global Labor History. Chicago: Haymarket.

Van der Linden, Marcel (2015) The Crisis of the World's Old Labour Movements. In Labour and Transnational Action in Times of Crisis, edited by Andreas Bieler, Roland Erne, Darragh Golden, Idar Helle, Knut Kjeldstadli, Tiago Matos and Sabina Stan. London: Rowman and Littlefield.

Visser, Jelle (2006) Union Membership Statistics in 24 Countries. Monthly Labour Review, January 2006: 38-49.

\section{BIOGRAPHICAL NOTE}

MARCEL VAN DER LINDEN served for fourteen years as research director of the International Institute of Social History, where he is now a senior fellow. He is also professor of Social Movement History at the University of Amsterdam, and President of the International Social History Association. His books include Transnational Labour History: Explorations (Aldershot: Ashgate, 2003), Workers of the World. Essays toward a Global Labor History (Chicago: Haymarket, 2010), and Beyond Marx. Theorising the Global Labour Relations of the Twenty-First Century (Chicago: Haymarket, 2014, edited with Karl Heinz Roth). [Email: mvl@iisg.nl] 